\title{
Bullying Among Secondary School Students in Malaysia: A Case Study
}

\author{
Norshidah Mohamad Salleh ${ }^{1} \&$ Khalim Zainal ${ }^{2}$ \\ ${ }^{1}$ Faculty of Education, Universiti Kebangsaan Malaysia, Malaysia \\ ${ }^{2}$ Center for General Studies (CITRA), Universiti Kebangsaan Malaysia, Malaysia \\ Correspondence: Norshidah Mohamad Salleh, Faculty of Education, Universiti Kebangsaan Malaysia, 43600 \\ UKM Bangi, Selangor, Malaysia. Tel: 603-8921-6258. E-mail: nshidah@ukm.edu.my
}

Received: July 22, 2014 Accepted: November 5, 2014 Online Published: December 21, 2014

doi:10.5539/ies.v7n13p184 URL: http://dx.doi.org/10.5539/ies.v7n13p184

\begin{abstract}
Bullying is an issue that is difficult to be eliminated in schools. Bully activity in school is a discipline problem and may interrupt the teaching and learning process. It often receives attention from parents who are concerned that such activity can develop into fights, which can lead to serious injury or even death. The study was conducted in one secondary school in Kuala Lumpur. The case study intends to gather in depth information about bullying factors in school. The school was chosen based on the information from teachers about the existence of a relatively serious case of bullying. From in depth interviews that was conducted towards 20 students, the researcher found that bullying factors included aspects of the students personalities such as ego, irritability, revenge, fun, the influence of others and elements of racism.
\end{abstract}

Keywords: bullying, disciplinary problems, students, bullying factors

\section{Introduction}

Bullying can be described as a way of treating people roughly with the intent of showing one's strength. Indirectly, it makes the victim feel weak and respect the bullies. In other words, bullying is aggressive behavior, which can be either physical or psychological, performed repeatedly with a victim and aims to make them feel uncomfortable, insecure, and isolated from those around them. Overall, bullying is a negative attitude: it makes other people into victims and may cause illness and discomfort to others (Khalim \& Norshidah, 2007).

Khalim (2014), categorized bullying into two types; direct and indirect. Direct bullying involves physical contact such as hitting, punching, kicking, threatening, slapping, pulling, pushing, or pinching to cause injuries to the victim. This is also known as physical bullying. The most violent forms of this bullying may cause death. Indirect bullying with insults and teasing effects the victim in psychological and emotional ways. It is also known as a mental bully. For example, if the student's name or the name of their father is quite unusual, then other students might tease them for it. While this type of bullying receives less attention from mass media, it is quite serious. Both categories of bullying are very dangerous because they can affect the emotional and social development of a student. If bullying occurs within 10-15 percent, it is considered serious.

Bullying is an issue that continues to get attention from researchers, educators, parents and students (DeVoe et al., 2005). There is a general view that considers verbal bullying a common aspect of childhood. Every day 160,000 students are afraid to go to school for fear of bullying (Edwards, 2004). However, the researchers found that bullying is a problem that can affect a student's future life (DeVoe, Kaffenberger, \& Chandler, 2005).

In Malaysia, several examples demonstrate that bullying in schools should be given serious attention. For example, a student from one of the school in Kuala Lipis, Pahang, faces the risk of paralysis of his entire life after being kicked in the back with police cadet's shoes into a closet by a group of form five and form three students. The victim was bullied by form five students and form three students who knocked him down with a wooden closet. Consequently, he suffered spinal cord injuries and may be permanently paralyzed. In addition, there is the case of another student in a secondary in Batu Pahat who lost his kidney and, spleen, and suffered damage to his liver, and gall bladder after being beaten by a group of senior students (New Sunday Times, 7 April 2004). Another case, a boy was beaten to death at the hostel dorm. Cyber-bullying has also been exposed on YouTube in Malaysia. The latest victim was a form three students from Sarawak were bullied by ten students also at the hostel dorm (Berita 
Minggu, 1 March 2009). Such incident proved that bullying is a very serious matter, which gave high concern from teachers, parents and the Ministry of Education. The following section will discuss past studies related to school bullying

According to De Voe, Kaffenberger, and Chandler (2005), bullying can be categorized as a breach of discipline in school. It is a disciplinary issue that has attracted attention from the society and mass media. This is because victims of bullying have a higher risk for experiencing various psychological problems such as social and emotional disturbances. Victims of bullying fear being in school or classrooms because they often become the targets of bullying. This leads to changes in behavior; truancy, depression and a variety of behaviors that lead to failure in school. This is a serious issue that needs to be addressed by the school (Edwards, 2004).

There are several studies on the behavior of bullying in Malaysia. Abdul-Latif (2005) carried out a study on 480 students in Johor. The study found that only $22.7 \%$ stated that they had been bullied once. $2.5 \%$ of students said they were bullied once to twice a week, while $5.6 \%$ said they were bullied once or twice per month and $11.9 \%$ said they were rarely bullied (once or twice a year). This measure indicates the low level of bullying behavior especially in the Batu Pahat district. Meanwhile, Noran-Fauziah (2004) has demonstrated that $95.8 \%$ of middle school students and $82.7 \%$ primary school students were psychologically bullied while $65.3 \%$ of middle school students and $56 \%$ of elementary school students were physically bullied. A review by Mahadi (2007) among students of religious school in Sarawak, found that verbal bullying is the most dominant form of bullying among students. The study showed that physical bullying is more dominant than emotional bullying. The study also found that the students often became bullies because they wanted to show that they were strong, and that older students did it to boast.

Study on bullying abroad such as a study by Verkuyten and Thijs (2002). Found that one of the reasons for bullying is racism. Their study in Netherlands demonstrated that existing racism was closely related to the processes of the bullying. Turks ethnic, Surinamese and Moroccans often become victims of bullying by whites in Holland. This lead to fights, insults and a feeling of alienation from whites among these ethnic groups. In Ireland, bullying is also closely linked to issues of racism between whites with Chinese, South Asians, and Black Africans (Connolly, 2002). Studies in the United States showed 14\% of pupils between the ages of 12 to 18 years had been bullied in school: $13 \%$ physically, and $7 \%$ mentally. The number of students who bully seems too decreased as grade level in school increases (De Voe et al., 2005). Past studies clearly describe the seriousness of bullying. Such study should be conducted in Malaysia to analyze the problems of bullying in local schools. This will give additional information to implement more proactive measures to be taken by school administrators to curtail the problems of bullying among students.

\section{Theoretical Framework}

In discussing negative behaviors such as bullying, Sigmund Freud's psychoanalytic theory, states that there are three internal elements that often collide and try to assert themselves (Woolfolk, 2012). These three elements are the Id, Ego and Superego. These three factors often conflict with each other. The Id refers to base elements such as pleasure. The Ego refers to the elements that affect the individual, the person understands the values and principles of human societies and cultures, but still violates and refuses to comply with these resolutions. The Superego refers to the element that understands the value of human societies and cultures as well as regulations and will submit to the resolving power of the individual. If the individual achieves the superego then they will act according to the rules in the framework of religion and society. Bullies are controlled by the Id and Ego. There are bullies that bully just for the fun of it. They also recognize that bullying is not accepted because their actions are against the school rules and religion. Their behavior would invite disciplinary action if school authorities caught it.

Humanistic theory also emphasized the development of behavior through external influences such as peers, family, the environment and so on, and the individual's ability to choose how to behave (Woolfolk, 2012). In some cases, their peers or the effects of watching violent films influence bullying behavior. This is supported by Bandura (1986), in Social Learning Theory, which states that learning occurs through observation. Children who often watch violent films will be affected by such violence. However, according to humanistic theory, individuals also have the ability to choose how to behave. If he chooses not to act roughly toward others, he is capable of doing so. The two theories give the individual the onus of choosing to act as a bully.

\section{Methods}

This is a case study whereby interviews were conducted in one of the secondary school in Kuala Lumpur, Malaysia. Thus, the limitation of the study is only in this particular secondary school in Kuala Lumpur. The result of the study cannot be made generalization of bullying problems in Malaysia. Interviews were conducted among twenty students who were involved in bullying their peers in the school. The age of the respondent are between 16 and 17 . 
All of the students were male. Nine of them were Malays, six were Indians and five Chinese. The information for choosing the respondent was given by the Senior Assistant of Student Affairs of the school. A focused interview was carried out to acquire information about the factors that encouraged bullying. The researcher also obtained information about the nature of bullying that happened in the school. Important themes related to the factors that encouraged bullying was extracted from the answers given by the respondents. These themes served as the basis for discussing the factors that contributed for bullying among the students.

Question of the study

1) Why were the students involved with bullying at school?

2) What encouraged bullying behavior?

3) What actions did the school reacted to address bullying?

4) What were the results of these disciplinary actions?

Data analysis is descriptive with the percentages. The information from the interviews was transferred in the form of verbatim. The major themes were discussed below.

\section{Results}

The findings showed that there were various factors that encouraged bullying. Among them is the desire to make money. The money was used to purchase cigarettes outside schools or eat at the canteen during lunch hour in school. The amount of money collected did not exceed RM 10.00. The study found that these bullies were not from low income families. They are able to purchase cigarettes or food in the canteen on their own but they were more satisfied earning money from other people. Most of the students come from middle or upper class families, in other words, families without financial problems. They felt satisfied earning money by bullying. The findings are in line with research by Wan-Salwina et al. (2014) who found no association between bullying and low social economic status.

15 students stated that they defended friends because of personal feelings of belonging. Of the 15 students, 9 were Malays, 4 were Indians and 2 were Chinese. They would act at any time to defend students of their ethnic when bullied by other ethnic. Sometimes bullying between ethnic groups occurred because of actions as trivial as eye contact. These incidents led to verbal insults, which in turn led into fights between students of different ethnic groups. These were serious physical bullying incidents because it involved the use of weapons such as iron, wood and knives. This led to a more serious incident, which involved fight between ethnic groups outside the school compound. The schools under the study had seen a series of fights involving ethnic groups in the school that spread out of the school. Sometimes students involved with bullying other ethnic groups stated that the other ethnic group started the fight. According to the statement given by the disciplinary teacher of the school, fights between ethnic groups occurred in the canteen while all the students were eating. This is where the ethnic difference is seen most clearly, when students involved with the fights are able to encourage other students from the same ethnic groups to help them. The researchers even saw fights while attempting to collect data on the schools involved. When a student asked the question why the fights occurred, the response received was "Those students just love to fights with my ethnic. They humiliate us by saying our ethnic as stupid and lazy. The student continued, “...Then they started beating students from my ethnic. That's an insult to all of us. I will not just let my friends beaten up and humiliated!" The student added, "...Sometimes it seems like the teacher will protect pupils of their own race and blame us alone." These are the reason given by students who bullied.

Other students said they bullied because they were unhappy seeing the success of other students. Jealousy caused bullies to use harsh language against the victim. This has to do with the student's sense of inferiority to others who are more intelligent. They may assume that successful students are arrogant and egoistic or "trying to show off." Finally, some students said they bullied because they had been hired to do so by friends. They were hired to threaten and beat up other students. They did these usually for wages ranging from RM5.00 to RM20.00. Those who earn money in this way are also from a well being families. These students, 5 in total, have a great physique. People who paid them usually hired a bully because of trouble over girlfriends among the students, of if a boyfriend seduced by other girl students in the school. These are the main reasons that mercenary bullies admitted. 
Table 1. Answers of students involved in bullying

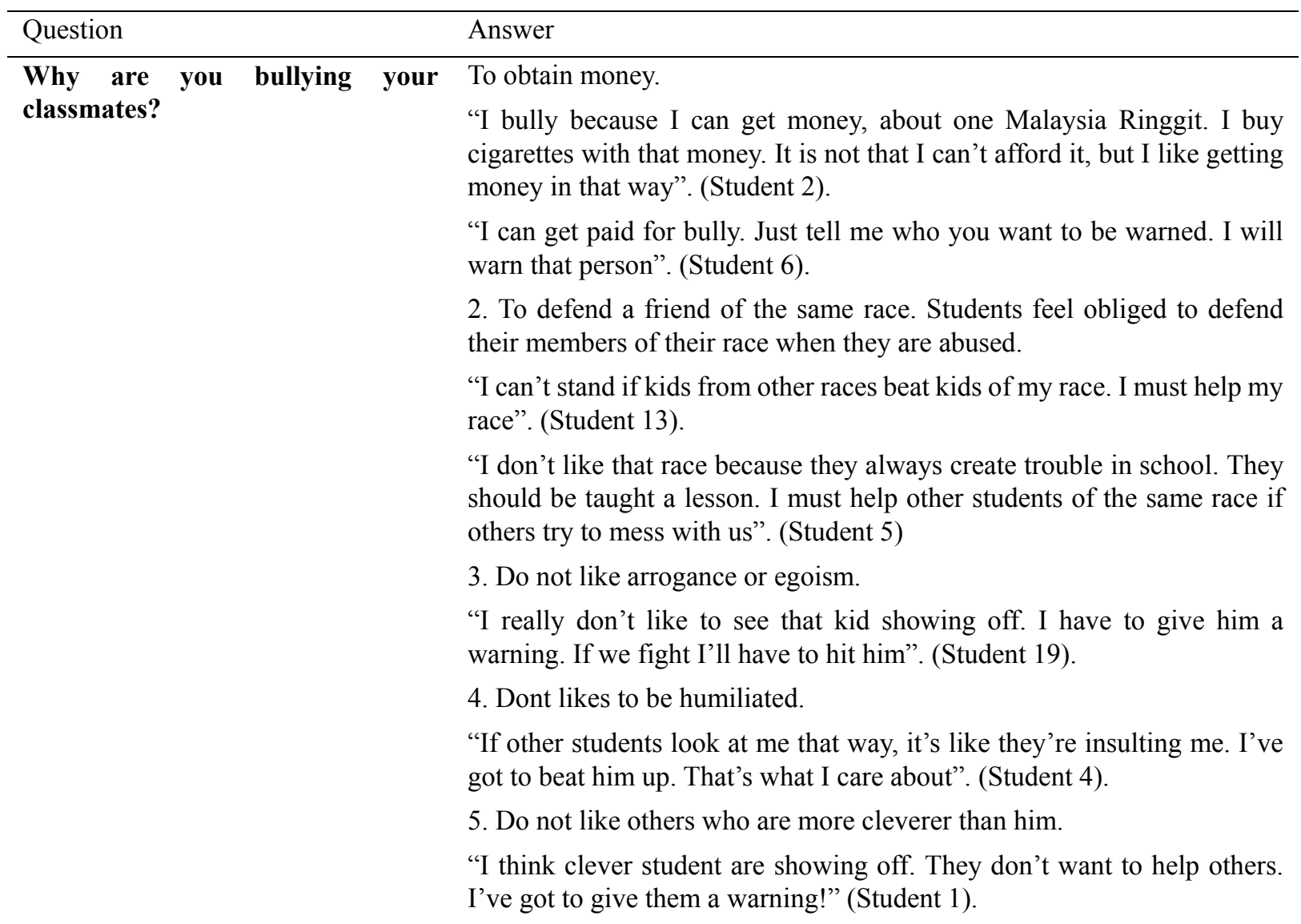

\section{What is the type of bullying?}

Are you bullying alone or together with other?

Do you feel satisfied after bullying your classmates?

What kinds of bullying have you done to your friends?

18 students stated that they bullied with other students. Only 2 students bullied others by themselves.

The majority (15 students) said they were satisfied. The 5 other students claimed they had not been satisfied.

12 bullies attacked physically with punches and kicks.

5 bullies had used wood and knives several times.

3 bullies had only used hurtful words.

3. What actions has the school taken to handle bullying at school?

12 students were suspended from school for one week and parents were called to discuss the issue with the school.

5 students were suspended from school for two weeks and parents were called to discuss the issue with the principal or Senior Assistant of Student Affairs.

3 students were only warned.

All students involved were directed to make an agreement with their parents that they would behave better.

All pupils were given counseling by a school counselor. 


\section{What were the effects of 18 students were no longer involved in bullying.}

disciplinary action by the school? 2 students are facing a school transfer on their parents' initiative. These students used weapons to bully other students even after having been suspended and signing a letter of agreement.

12 students acknowledge their actions influenced by emotion. They recognized that their actions were not right and were aware of the mistakes that they had made.

8 students considered their actions justified because their victims were arrogant and needed to be taught a lesson.

The study also found many cases of bullying done in groups of more than one student. Only two students surveyed bullied on their own. 17 bullies used physical contact when bullying, including slaping, kicking and hitting with hands, sticks and knives in addition to verbal abuse with words of warning, curses and insults. 3 bullies relied soley on verbal bullying surch as abusive words, warnings, curses and insults.

Table 2. Action plan for the offense of bullying

\begin{tabular}{lll}
\hline No. & Offense of bullying & Action \\
\hline 1. & Bullying for the first time & First Warning \\
& Counseling \\
& Letter of Notice to Parents \\
& One Strike with a Cane (if severe)
\end{tabular}

2. Bullying for the second time

3. Bullying for the third time

4. Bullying for the fourth time

\section{Second Warning \\ Counseling}

Parents called in to discuss and sign an agreement

One Strike with a Cane

\section{Third Warning}

Counseling

One strike with a cane

Two weeks of school suspension

*After suspension, parent will sign a letter to gurantee that their child will behave accordingly with the school's regulation.

Expelled from school

The policy of the school is to give a first warning, second warning, last warning, school suspension and then expulsion. When the first warning is issued, students are sent for counseling. For recurring cases, the second warning issued to students, they are caned once on the buttocks and parents are called to discuss and ratify an agreement to assure their children will behave well and not repeat the offense and agree to a second round of counseling. If the behavior continues the students are caned once, suspended from school for two weeks, the parents sign a final agreement guaranteeing that their son will not repeat the offense and the students are given counseling a third time. If they repeat such acts, the student will be expelled from schools and are not permitted to make an appeal for the same school. So far, 18 students have demonstrated behavioral changes, while 2 students involved with bullying are undergoing suspension of schooling for two weeks because they have reached their third warning. The parents of the 2 students plan to transfer their children to another school for fear that their child's suspension has not changed their bullying behavior. 18 of the student's admitted they were emotional while 
bullying other students and have acknowledged their mistakes to the parents and teachers.

\section{Discussion}

These findings show that, the racial element for bullying was fairly significant. This was an unhealthy development as the Government is emphasizing the concept of "One Malaysia". Based on the answers provided, bullies are willing to defend a friend when they are humiliated or beaten up by students of other races. Even more unfortunately, teachers also seem to play a role in encouraging racism in the school. This is beyond expectations. Teachers are a model to their students. Students look up to these models and will emulate them in life. This is dangerous for a multi-ethnic nation. This is in line with Bandura's Social Learning theory (1986) that says humans act are based on what is observed. If a teacher is biased toward a certain ethnic, students will observe this behavior and it is possible that they will adopt it in the future. This is a very dangerous thing for countries that have a diversity of ethnic groups. While this is only one case study, these findings suggest that potential cases of bullying in other racially mixed school might also take on this racial element. The Ministry of Education should always be in contact with the State Education Department regarding matters concerning ethnicity because it will hinder building future human capital to develop good citizens of the country. This can affect the unity among different ethnics and affect the stability of the nation (Khalim, Johari, Fazilah, Mansor, \& Norshidah, 2014). The Ministry of Education has carried out several programs so that the basis of strong unity can be imbued and reinforced in schools because they are the human capital that should be given serious attention. Schools involved however have acted wisely by implementing an integrated Student Unity Program (RIMUP) for bridging racial divides among students. However, teachers who are from various ethnic groups should play an active role in support of the efforts of the Ministry to make the involvement of the students more comprehensive. We do not wish to see a few teachers that create racial tensions among students. According to the Social Learning Theory, aggressive behavior is instrumental behavior controlled by strengthening and external rewards (Bandura, 1986). Teachers need to cultivate an environment of unity at schools by acting with a positive attitude toward students different ethnics. Students will emulate teachers if they act in this way.

The finding of the study also shows that physical bullying is a serious issue in schools. It was supported by other research done in Malaysia (Wan-Salwina et al., 2014; Norelawaty, Zuria, \& Noran-Fauziah, 2008). Students involved used sharp weapons such as knives and iron as well as physical attacks such as kicking and beating. This behavior can lead to serious injury or even death. These findings demonstrate that the school is no longer safe for students, in accordance with studies conducted by Noran-Fauziah (2004). The use of dangerous weapons is an aggressive behavior. Bullies could have imitated the behavior of characters in the many violent films shown in local theaters (Connor, 2002). One of the reasons why those who observe bullying will likely to adopt bullying behavior themselves (Khalim, 2014). The Social Learning Theory is a blended of Theoretical Reinforcement (Stimulus-response) and Cognitive Theory. It explains human behavior as the result of interactions between cognition and the environment and human behavior. Even so, Social Learning Theory does not ignore the cognitive aspect. People still have the ability to shape their own behavior. This is where the role of teachers in helping students to make the choice between good and bad behavior becomes important. The teacher must not be biased. They should not be influenced by elements of racism or ethnocentrism.

Verbal bullying was the most widely performed type of bullying. Although it might not seem to have a direct effect, it must be controlled because it may affect the victim's emotional and psychological state. Victims of bullying will have the sense of fear to attend school. It is possible that they will become resentful and bully others one day. Bullying is also associated with low self-esteem (Khalim, 2014). Through bullying, bullies with low self-esteem boost their self-esteem by victimizing others. Bullies wish to dominate others (victim) to feel powerful and appreciated while victims of bullying feel a loss of appreciation and self-confidence. Healthy self-esteem is one of the basic needs of human beings, and the inability to meet or satisfy these needs will have a deep negative impact on the growth and development of youths, especially students in secondary schools. Bullying is destructive and damages self-esteem. It needs to be disciplined and dealt with immediately in children and teenagers. Bullying therefore must be reported to teachers, who also need to be sensitive to such actions. The school needs to move decisively with parents, the State Education Department and the Ministry of Education should provide support to teachers so that teachers can curb bullying more effectively. The school should play a more proactive role by promoting an aggressive student-specific plan. This may be initiated by the Counseling Unit or the Moral Education Unit in collaboration with Disciplinary Unit in various schools. Comprehensive school-based programs are the most effective way to address the problem of bullying in schools (Khalim, 2014).

\section{Conclusion}

Bullying is a problem that must be addressed in an integrated manner by parents and teachers with support from the 
State Education Department and Ministry of Education. Each need should interact effectively and professionally, and did not allow emotion to disrupt the process. In schools, bullying must be identified at the micro before it spreads to the macro level. Schools have to plan programs that nurture students from various ethnic groups, because unhealthy activities such as bullying can affect inter-ethnic relations in schools. A comprehensive program involving the entire school machinery such as teachers and parents must be carried out with a full sense of responsibility so that we may develop quality human capital for the sake of our beloved nation. The school's governing body must also be transparent in reporting disciplinary problems especially involving bullying and fights, to the Ministry of Education, which can then be more proactive at the national level. It will facilitate the development of human capital more effectively. The home institution can also play an important role in promoting the welfare of its members. The family is an important locus in the process of understanding and improving personal character and the communal environment among family members and especially students. In the family, the guidance of parents will shape the personality of individual students. All parties need to work together to solve problems such as bullying, because we do not want schools as an educational institution to encourage violent and cruel behavior. They must instead provide training intended to develop people that are useful to our society, nation and religion.

\section{References}

Abdul-Latif, A. (2005). Persepsi guru dan pelajar terhadap perlakuan buli di kalangan pelajar sekolah menengah daerah Batu Pahat (Unpublished Master's thesis). Faculty of Education, Universiti Teknologi Malaysia, Skudai Johor.

Bandura, A. (1986). Social foundations of thought and action: A social cognitive theory. Upper Saddle River, NJ: Prentice Hall.

Connolly, P. (2002). Race and racism in Northern Ireland: A review of the research evidence. Research Output Report.

De Voe, J. F., Kaffenberger, S., \& Chandler, K. (2005). Student reports of bullying results from the 2001 school crime supplement to the National Crime Victimization Survey Statistical Analysis Report. U.S. Department of Education Institute of Education Sciences National Center For Education Statistics.

De Voe, J. F., Peter, K., Kaufman, P., Miller, A. K., Noonan, M., Snyder, T. D., \& Baum, K. (2005). Indicators of school crime and safety: NCES 2005-002/NCJ 205290. Washington, DC: U.S. Departments of Education and Justice.

Edwards, C. H. (2004). Classroom discipline and management (4th ed.). New York: John Wiley \& Sons Inc.

Khalim, Z. (2014). Pengurusan disiplin pelajar sekolah. Universiti Kebangsaan Malaysia: Bangi.

Khalim, Z., \& Norshidah, M. S. (2007). The implementation of the penalty system program for vandalism in school: A case study. The International Journal of Learning, 14(9), 123-131.

Khalim, Z., Johari, T., Fazilah, I., Mansor, M. N., \& Norshidah, M. S. (2014). Racial bahaviour among secondary school students. In A. Gunstone (Ed.), Devoloping sustainable education in regional Australia (pp. 99-116). Monash University Publishing: Victoria, Australia.

Mahadi, K. (2007). Tingkah laku buli dalam kalangan pelajar Sekolah Menengah Kebangsaan Agama Di Sarawak (Unpublished Master's thesis). Faculty of Education, Universiti Teknologi Malaysia, Skudai Johor.

Noran-Fauziah, Y. (2004). Tingkah laku buli di sekolah: Apa yang boleh kita lakukan. Paper presented at The Third Principle Conference. Universiti Malaya 17 March.

Norelawaty, S., Zuria, M., Noran-Fauziah, Y. (2008). Tingkah laku buli dalam kalangan pelajar perempuan sekolah rendah. Jurnal PSIMA, 20(1), 1-20.

Verkuyten, M., \& Thijs, J. (2002). Racist victimization among children in the Netherlands: the effect of ethnic group and school. Ethnic and Racial Studies, 25(2), 310-331. http://dx.doi.org/10.1080/01419870120109502.

Wan-Salwina, W. I., Nik, R. N. J., Hatta, S., Marhani, M., \& Shamsul, A. S. (2014). Why do young adolescents bully? Experience in Malaysian schools. Comprehensive Psychiatry, 55, 114-120. http://dx.doi.org/10.1016/j.comppsych.2013.05.002

Woolfolk, A. (2012). Educational psychology (12th ed.). Boston: Pearson Education, Inc. 


\section{Copyrights}

Copyright for this article is retained by the author(s), with first publication rights granted to the journal.

This is an open-access article distributed under the terms and conditions of the Creative Commons Attribution license (http://creativecommons.org/licenses/by/3.0/). 